\title{
IMPLEMENTASI KEBIJAKAN PERSAMPAHAN BERBASIS COLLABORATIVE GOVERNANCE DI KOTA MAKASSAR
}

\author{
Nurimna Fadliah ${ }^{1}$ Fatmawati $^{2}$, Hafiz Elfiansyah Parawu ${ }^{3}$ \\ ${ }^{1,2,3}$ Universitas Muhammadiyah Makassar, Indonesia \\ e-mail : fadliahnurimna@gmail.com
}

\begin{abstract}
Abstrak
The purpose of this study is to describe and analyze the implementation of collaborative governance-based waste policies in Makassar City, and what determinant factors are encountered in the implementation of Collaborative Governance-based waste management policies in Makassar City. This research uses qualitative research. The instruments used in this study were interviews, observation and documentation. The number of informants as many as 5 people who were determined by purposive sampling. The answers from the informants were analyzed and described descriptively. The results of the study indicate that the implementation of collaborative governancebased waste policies in Makassar City has been carried out. Organizational and inter-organizational behavior has implemented a waste policy based on collaborative governance in Makassar City. Every waste policy actor in Makassar City (UPT Bank Garbage, YPN and BSU) already has a commitment to collaborate in implementing solid waste policy in Makassar City. This can be seen from the statements of each party and evidenced by the coordination between institutions. Every waste policy actor in Makassar City (UPT Bank Garbage, YPN and $B S U)$ has implemented the waste policy discretionary. The behavior of the target group is implemented according to the positive response from each Waste Bank Unit (BSU) which is also the target group. This can be seen from the positive response to the waste policy in Makassar City. Supporting factors in the process of applying the principles of good governance are communication factors and resource support factors.
\end{abstract}

Keywords: Policy Implementation, Collaborative, Governance

\begin{abstract}
Abstrak
Tujuan penelitian ini untuk Mendeskripsikan dan menganalisis implemetasi kebijakan persampahan berbasis collaborative governance di Kota Makassar, dan faktor faktor determinan apa saja yang dihadapi dalam Implementasi kebijakan pengelolaan sampah berbasis Collaborative Governance di Kota Makassar. Penelitian ini menggunakan penelitian kualitatif. Instrumen yang digunakan dalam penelitian ini adalah wawancara, observasi dan dokumentasi. Jumlah informan sebanyak 5 orang yang ditetapkan secara purposive sampling. Jawaban dari informan dianalisis dan dijabarkan secara deskriptif. Hasil penelitian menunjukkan bahwa Implememntasi kebijakan persampahan berbasis collaborative governance di Kota Makassar sudah terlaksana. Perilaku organisasi dan antar organisasi telah mengimplemtasikan kebijakan persampahan berbasis collaborative governance di Kota Makassar. Setiap pelaku kebijakan persampahan di Kota Makassar (UPT Bank Sampah, YPN dan BSU) sudah memiliki komitmen untuk berkolaborasi mengimplementasikan kebijakan persampahan di Kota makassar. Hal tersebut dapat dilihat dari pernyataan masing-masing pihak dan dibuktikan dengan adanya koordinasi antar Lembaga. Setiap pelaku kebijakan persampahan di Kota Makassar (UPT Bank Sampah, YPN dan BSU) telah mengimplemetasikan secara diskresi kebijakan persampahan tersebut. Perilaku kelompok sasaran diimplemetasikan sesuai respon positif dari setiap Bank Sampah Unit (BSU) yang juga sebagai kelompok sasaran. Hal tersebut dapat dilihat dari adanya respon yang positif atas kebijakan persampahan di Kota Makassar. Faktor pendukung dalam proses penerapan prinsip-prinsip good governance adalah faktor komunikasi dan factor dukungan sumberdaya.
\end{abstract}

Kata Kunci: Implemetasi Kebijakan, Collaborative, Governance 


\section{PENDAHULUAN}

Faktor penting yang menyebabkan terjadinya perubahan lingkungan hidup yang tidak baik adalah adanya peningkatan pertumbuhan populasi penduduk yang tidak diimbangi dengan peningkatan kualitas perilaku hidup masyarakat dalam menjaga keseimbangan lingkungan hidup. Dengan pertambahan penduduk dan perubahan pola hidup tersebut mengakibatkan bertambahnya masalah sampah baik itu volume, jenis maupun karakteristik sampah yang beragam.

Permasalahan sampah dewasa ini merupakan permasalahan nasional yang memerlukan perhatian dan penanganan serius terutama di kota-kota besar di Indonesia. Pengelolaan sampah perlu dilakukan secara komprehensif yang berkelanjutan dan terpadu mulai dari pengumpulan sampah hingga proses pengolahannya. Amanat Undang-undang Dasar 1945 Pasal $28 \mathrm{H}$ ayat (1) menyatakan memberikan hak kepada setiap orang untuk mendapatkan lingkungan hidup yang baik dan sehat kemudian membawa konsekuensi hukum bahwa pemerintah wajib memberikan pelayanan publik dalam pengelolaan sampah sebagai pihak yang berwenang dan bertanggung jawab meskipun dalam operasional kegiatan pengelolaan sampah dapat bekerja sama dengan badan usaha serta pelibatan peran serta masyarakat atau kelompok mayarakat yang bergerak di bidang persampahan.

Menurut ketentuan dalam Undang-Undang Republik Indonesia Nomor 18 Tahun 2008 tentang Pengelolaan Sampah (selanjutnya disingkat UU Pengelolaan Sampah) Pasal 1 ayat 1 Sampah adalah sisa kegiatan sehari-hari manusia atau proses alam yang berbentuk padat.

Menurut BAPPENAS (2010) yang dikutip Suwerda (2012:3) dikatakan bahwa permasalahan utama di dalam pengelolaan sampah adalah rendahnya akses terhadap layanan pengelolaan sampah. Kondisi ini disebabkan oleh lima faktor, antara lain: a) Masih belum memadai perangkat peraturan yang mendukung pengelolaan sampah; b) Penanganan sampah belum optimal; c) Minim pengelolaan layanan persampahan yang kredibel dan profesional; d) Belum optimal sistem perencanaan pengelolaan sampah; e)
Terbatasnya pendanaan untuk mendukung keseluruhan aspek pengeloaah sampah.

Pengelolaan persampahan kemudian menjadi tanggung jawab daerah disebabkan karena pemerintah daerah memiliki kewenangan pengaturan dalam Peraturan Daerah berdasarkan delegasi dan atribusi.

Berbagai kebijakan telah dikeluarkan dan diimplementasikan oleh Pemerintah Kota Makassar untuk menyelesaikan permasalahan di bidang persampahan. Namun hasilnya sampai sekarang belum mampu menyelesaikan permasalahan sampah. Jumlah timbulan sampah semakin bertambah sementara kapasitas TPA semakin terbatas. Pemerintah sudah saatnya membagi beban pengelolaan sampah secara kolaboratif dengan berbagai stakeholders. Pengelolaan persampahan akan berjalan efektif apabila dilaksanakan secara bersama-sama bukan hanya tugas dari pemerintah. Kerja sama yang dimandatkan dalam Undang-Undang nomor 18 Tahun 2008 tentang Pengelolaan Sampah adalah kerja sama antara pemerintah sebagai pembuat kewenangan dengan dunia usaha (swasta) /kelompok masyarakat yang bergerak di bidang persampahan dan masyarakat. Kerjasama yang terbangun dalam pelayanan publik diantara pihak-pihak terkait tersebut akan menciptakan suatu Collaborative Governance. Konsep Collaborative Governance menekankan pada penyelenggaraan pemerintahan yang kolaboratif.

Pengelolaan sampah di Kota Makassar sebagai salah satu kota Metropolitan sebagaimana amanat dari Undang-Undang Nomor 18 Tahun 2008 tentang Pengelolaan Sampah tertuang dalam Peraturan Daerah Kota Makassar Nomor 4 Tahun 2011 tentang Pengelolaan sampah dalam Pasal 4 disebutkan bahwa pengelolaan sampah bertujuan untuk meningkatkan kesejahteraan masyarakat dan kualitas lingkungan serta menjadikan sampah sebagai sumber daya. Kemudian pada pasal 11 ayat 2 (b) disebutkan bahwa pengurangan sampah dilakukan melalui kegiatan fasilitasi pada masyarakat dan dunia usaha dalam mengembangkan dan memanfaatkan hasil daur ulang, pemasaran hasil produk daur ulang dan guna ulang sampah. Dan pada pasal 31 ayat 1 disebutkan Pemerintah Kota dapat bermitra dengan Badan Usaha dan kelompok masyarakat dalam pengelolaan sampah. 
Salah satu bentuk kerja sama antara Pemerintah Kota Makassar dalam hal ini UPT Bank Sampah dengan Lembaga/ Swasta adalah adanya kerjasama penanganan dan pengurangan sampah dengan Lembaga Swadaya Masyarakat (LSM) peduli sampah, Bank Sampah Unit (BSU) dan beberapa pihak swasta atau vendor. LSM peduli sampah dan BSU, berperan dalam pengumpulan sampah sementara Swasta/Vendor berperan sebagai pembeli dari sampah yang telah dipilah berdasarkan jenis dan ukuran sampah. Peran Masyarakat adalah sebagai pengumpul sampah kemudian memilah dan menjual ke Bank Sampah Unit atau LSM peduli sampah.

UPT Bank sampah sebagai fasilitator dan pembuat kebijakan dituntut mampu memfasilitasi pihak-pihak yang berkerja sama baik itu dengan LSM, BSU maupun Vendor. Tetapi pada pelaksanaanya kolaborasi yang terjalin kurang optimal karena masih banyak LSM peduli sampah maupun Bank Sampah Unit yang berjalan sendiri-sendiri. Sementara itu kejelasan dengan pihak swasta dengan hal ini vendor sebagai pengumpul dari sampah terpilah tidak dilengkapi dengan dokumen yang jelas. Belum optimalnya kolaborasi yang dilakukan oleh stakeholders terkait implementasi kebijakan persampahan berakibat ditandai dengan belum adanya kepercayaan antar aktor, pemahaman bersama dan belum adanya kerja sama secara keseluruhan.

\section{Teori Kebijakan Publik}

Kebijakan publik bila dilihat dari hirarki kebijakan dapat bersifat nasional, regional maupun lokal seperti undang undang, peraturan pemerintah, peraturan presiden, peraturan menteri, peraturan pemerintah daerah/provinsi, keputusan gubernur, peraturan daerah kabupaten/kota, dan keputusan bupati/walikota. Easton (1969) memberikan definisi kebijakan publik sebagai the authoritative allocation of values for the whole society atau sebagai pengalokasian nilai-nilai secara paksa kepada seluruh anggota masyarakat.

Pressman dan Widavsky sebagaimana dikutip Budi Winarno (2002: 17) mengatakan bahwa kebijakan publik sebagai hipotesis yang mengandung kondisi-kondisi awal dan akibatakibat yang bias diramalkan. Robert Eyestone sebagaimana dikutip Leo Agustino (2008:6) mendefinisikan kebijakan publik sebagai "hubungan antara unit pemerintah dengan lingkungannya". Dari definisi tersebut oleh banyak pihak beranggapan masih terlalu luas untuk dipahami, karena apa yang dimaksud dengan kebijakan publik dapat mencakup banyak hal. Sedangkan menurut Nugroho, ada dua karakteristik dari kebijakan publik, yaitu:1) kebijakan publik merupakan sesuatu yang mudah untuk dipahami, karena maknanya adalah hal-hal yang dikerjakan untuk mencapai tujuan nasional; 2) kebijakan publik merupakan sesuatu yang mudah diukur, karena ukurannya jelas yakni sejauh mana kemajuan pencapaian cita-cita sudah ditempuh.

Thomas R Dye sebagaimana dikutip Islamy (2009: 19) mendefinisikan bahwa kebijakan publik sebagai "is whatever government choose to do or not to do" (apapaun yang dipilih pemerintah untuk dilakukan atau untuk tidak dilakukan). Penekanan dari definisi ini bahwa kebijakan publik merupakan perwujudan "tindakan" dan bukan merupakan pernyataan keinginan pemerintah atau pejabat publik semata. Di samping itu pilihan pemerintah untuk tidak melakukan sesuatu juga merupakan kebijakan publik karena mempunyai pengaruh (dampak yang sama dengan pilihan pemerintah untuk melakukan sesuatu.

Berdasarkan berbagai pendapat ahli mengenai kebijakan publik, dapat disimpulkan bahwa kebijakan publik merupakan serangkaian tindakan yang dilakukan atau pun tidak dilakukan oleh pemerintah yang berorientasi pada tujuan tertentu guna memecahkan berbagai masalah publik untuk kepentingan publik sendiri.

\section{Implementasi Kebijakan}

Salah satu tahap penting dalam proses kebijakan adalah tahap Implementasi. Implementasi dilaksanakan setelah sebuah kebijakan yang bertujuan jelas telah diputuskan oleh pembuat kebijakan. Implementasi adalah suatu rangkaian aktifitas dalam rangka menghantarkan kebijakan kepada masyarakat sehingga kebijakan tersebut dapat membawa hasil sebagaimana yang diharapkan (Afan Gaffar, 2009: 295). Rangkaian kegiatan tersebut di mulai dari tahap persiapan seperangkat peraturan lanjutan yang merupakan interpretasi dari kebijakan tersebut. Misalnya dari sebuah undang-undang kemudian memunculkan sejumlah Peraturan 
Pemerintah, Keputusan Presiden, maupun Peraturan Daerah, menyiapkan sumber daya guna menggerakkan implementasi termasuk di dalamnya sarana dan prasarana, sumber daya keuangan, dan penentuan siapa yang bertanggung jawab melaksanakan kebijakan tersebut, dan bagaimana mengantarkan kebijakan secara nyata ke masyarakat.

Daniel A. Mazmanian dan Paul A. Sabatier (1979) seperti yang dikutip oleh Solichin Abdul Wahab, mengatakan bahwa: memahami apa yang senyatanya terjadi sesudah suatu program dinyatakan berlaku atau dirumuskan merupakan fokus perhatian implementasi kebijakan, yakni kejadian-kejadian dan kegiatan-kegiatan yang timbul sesudah disahkannya pedoman-pedoman kebijakan Negara, yang mencakup baik usaha-usaha untuk mengadministrasikannya maupun untuk menimbulkan akibat/dampak nyata pada masyarakat atau kejadian- kejadian (Solichin Abdul Wahab, 1997: 64-65).

Pengertian implementasi yang telah disebutkan diatas apabila dikaitkan dengan kebijakan adalah sebenarnya kebijakan itu tidak hanya dirumuskan lalu dibuat dalam suatu bentuk positif seperti undang-undang dan kemudian didiamkan dan tidak dilaksanakan atau diimplementasikan, tetapi sebuah kebijakan harus dilaksanakan atau diimplementasikan agar mempunyai dampak atau tujuan yang diinginkan. Implementasi kebijakan merupakan suatu upaya untuk mencapai tujuan-tujuan tertentu dengan saranasarana tertentu dan dalam urutan waktu tertentu (Bambang Sunggono 1994:137).

Menurut Teori Implementasi Brian W. Hogwood dan Lewis A. Gun yang dikutip Solichin Abdul Wahab Adapun, syarat-syarat untuk dapat mengimplementasikan kebijakan negara secara sempurna, yaitu :

a. Kondisi eksternal yang dihadapi oleh badan atau instansi pelaksana tidak akan mengalami gangguan atau kendala yang serius. Hambatan- hambatan tersebut mungkin sifatnya fisik, politis dan sebagainya.

b. Untuk pelaksanaan program tersedia waktu dan sumber-sumber yang cukup memadai.

c. Perpaduan sumber-sumber yang diperlukan benar-benar tersedia. d. Kebijaksanaan yang akan diimplementasikan didasarkan oleh suatu hubungan kausalitas yang handal.

e. Hubungan kausalitas bersifat langsung dan hanya sedikit mata rantai penghubungnnya.

f. Hubungan saling ketergantungan kecil.

g. Pemahaman yang mendalam dan kesepakatan terhadap tujuan.

h. Tugas-tugas diperinci dan ditempatkan dalam urutan yang tepat.

i. Komunikasi dan koordinasi yang sempurna.

j. Pihak-pihak yang memiliki wewenang kekuasaan dapat menuntut dan mendapatkan kepatuhan yang sempurna. (Solichin Abdul Wahab,1997:71-78).

Sedangkan menurut Teori Implementasi Kebijakan George Edward III) yang dikutip oleh Budi winarno, faktor-faktor yang mendukung implementasi kebijakan, yaitu :

\section{a. Komunikasi}

Dalam proses komunikasi kebijakan terdapat tiga hal penting yang dibahas, yakni transmisi, konsistensi, dan kejelasan (clarity). Faktor pertama yang mendukung implementasi kebijakan adalah transmisi. Seorang pejabat yang mengimlementasikan keputusan harus menyadari bahwa suatu keputusan telah dibuat dan suatu perintah untuk pelaksanaanya telah dikeluarkan. Faktor kedua yang mendukung implementasi kebijakan adalah kejelasan, yaitu bahwa petunjuk-petunjuk pelaksanaan kebijakan tidak hanya harus diterima oleh para pelaksana kebijakan, tetapi komunikasi tersebut harus jelas. Sedangan Faktor ketiga yang mendukung implementasi kebijakan adalah konsistensi, yaitu jika implementasi kebijakan ingin berlangsung efektif, maka perintahperintah pelaksanaan harus konsisten dan jelas.

\section{b. Dukungan}

Pelaksanaan suatu kebijakan publik akan sangat sulit apabila pada pengimlementasiannya tidak cukup dukungan untuk pelaksanaan kebijakan tersebut.

\section{c. Pembagian Potensi}

Penyebab kegagalan implementasi suatu kebijakan publik juga ditentukan aspek pembagian potensi diantara para pelaku yang 
terlibat dalam implementasi. Dalam hal ini berkaitan dengan diferensiasi tugas dan wewenang organisasi pelaksana. Struktur organisasi pelaksanaan dapat menimbulkan masalah-masalah apabila pembagian wewenang dan tanggung jawab kurang disesuaikan dengan pembagian tugas atau ditandai oleh adanya pembatasan-pembatasan yang kurang jelas (Bambang Sunggono,1994: 149-153). Diperlukan penyesuaian waktu khususnya bagi kebijakan-kebijakan yang kontroversial yang lebih banyak mendapat penolakan warga masyarakat dalam implementasinya.

\section{Konsep Collaborative Governance}

Salah satu konsep yang dewasa ini menjadi satu kajian yang menarik dalam Ilmu administrasi Publik adalah Collaborative Governance. Collaborative Governance berfokus pada kebijakan dan masalah publik. Collaborative governance menghendaki terwujudnya keadilan sosial dalam memenuhi kepentingan publik. (Setyoko 2011: 16)

Anshell dan Grash menyatakan bahwa konsep Collaborative Governance merupakan respon terhadap beberapa kegagalan yang dialami oleh pemerintah seperti kegagalan dalam hal implementasi dan munculnya politisasi suatu kebijakan akibat dominasi aktor tunggal dalam perumusannya.

Adanya pergeseran paradigma dari government menuju governance memunculkan Collaborative governance sehingga menurut Cleveland, Harlan. 1972 melahirkan istilah "less government and more governance; atau juga munculnya istilah "governing without government" menurut Rhodes, R.A.W. 1996.. Selanjutnya, perubahan tersebut memunculkan beberapa karakteristik baru yang harus dimiliki oleh sebuah pemerintahan yang antara lain seperti aspek kekuasanaan pemerintah yang menyebar atau desentralistis dan tidak lagi sentralistis; pengambilan keputusan melalui sebuah konsensus yang dilakukan secara kolektif baik di ingkungan internal maupun eksternal dari organisasi pemerintah; dan hubungan atau relasi antar organisasi yang bersifat horisontal atau setara. Perubahan paradigma dari government ke governance menunjukkan bahwa perlunya gelombang baru reformasi pemerintahan kearah yang lebih baik.
Berdasarkan pendapat awal yang dikemukaan oleh Ansell dan Gash (Ansell, Chriss dan Alison Gashh. 2007) bahwa definisi collaborative governance sebagai "A governing arrangement where one or more public agencies directly engage non-state stakeholders in a collective decision-making process that is formal, consensusoriented, and deliberative and that aims to make or implement public policy or manage public programs or assets." (Collaborative governance adalah serangkaian pengaturan dimana satu atau lebih lembaga publik yang melibatkan secara langsung stakeholders non state di dalam proses pembuatan kebijakan yang bersifat formal, berorientasi konsensus dan deliberatif yang bertujuan untuk membuat atau mengimplementasikan kebijakan publik atau mengatur program publik atau asset).

Defenisi tersebut terdapat dapat dirumuskan menjadi beberapa kata kunci yang menekankan pada enam karakteristik, yaitu:

a. Forum tersebut diinisiasi atau dilaksanakan oleh lembaga publik maupun aktor-aktor dalam lembaga publik.

b. Peserta di dalam forum tersebut juga termasuk aktor non-publik

c. Peserta terlibat secara langsung dalam pembuatan dan pengambilan keputusan dan keputusan tidak harus merujuk kepada aktor-aktor publik.

d. Forum terorganisir secara formal dan pertemuan diadakan secara bersama-sama.

e. Forum bertujuan untuk membuat keputusan atas kesepakatan bersama, dengan kata lain forum ini berorientasi pada konsensus.

f. Kolaborasi berfokus pada kebijakan publik maupun manajemen publik. (Subarsono, 2016).

Dari beberapa definisi yang telah dikemukakan oleh para ahli tersebut diatas, maka dapat dirumuskan bahwa Collaborative Governance merupakan tata cara pengelolaan pemerintahan yang multipartner dengan melibatkan berbagai stakeholder baik secara langsung maupun tidak langsung, berorientasi pada konsensus, dan terjadi musyawarah dalam proses pengambilan keputusan kolektif. Collaborative Governance bukan hanya pelibatan beberapa stakeholder melainkan juga merupakan cara berperilaku dalam pelayanan publik. 
Dalam implementasi sebuah kebijakan perlu melibatkan banyak aktor, baik itu dari unsur pemerintah, swasta hingga masyarakat sipil. Oleh sebab itu maka Collaborative Governance dalam Implementasi kebijakan wajib dilakukan. Hal ini mengingat bahwa keterbatasan dari kemampuan lembaga pemerintah menjalankan fungsi-fungsinya dalam pelayanan publik. Keterlibatan aktor lain diluar pemerintah menjadi sebuah kebutuhan. Salah satu pakar yang mengemukakan pendapat tentang pentingnya melakukan Collaborative Governance adalah Ansel dan Gash. Ansel and Gash mengatakan bahwa Collaborative Governance penting dilakukan antara lain adalah karena dilatarbelakangi oleh perkembangan organisasi dan tumbuhnya pengetahuan dan kapasitas institusi atau organisasi seiring dengan pengalamanpengalaman yang diperoleh dari lingkungan selama organisasi tersebut bekerja dalam rentang waktu tertentu.

Karena melibatkan banyak stakeholder, seringkali Pelaksanaan Kolaborasi yang dilakukan tidak berjalan dengan lancar tanpa hambatan, seringkali menyebabkan keberlangsungan proses kolaborasi menjadi terhambat. Diperlukannya penyesuaian antar pemangku kepentingan agar bisa menyatukan visi, misi, tujuan yang dimiliki untuk diwujudkan bersama. Karena berasal dari sektor yang berbeda, masing-masing stakeholder seringkali memprioritaskan kepentingan dan tujuannya sendiri dibandingkan tujuan yang telah ditetapkan bersama stakeholder lain. Hal ini adalah salah satu yang menghambat suksesnya kolaborasi, meskipun tidak sepenuhnya pihak yang mengutamakan tujuannya tersebut melakukannya dengan tanpa alasan.

\section{Pengertian Sampah}

Pengertian sampah adalah suatu yang tidak dikehendaki lagi oleh yang punya dan bersifat padat. Sementara didalam UU No 18 Tahun 2008 tentang Pengelolaan Sampah, disebutkan sampah adalah sisa kegiatan sehari hari manusia atau proses alam yang berbentuk padat atau semi padat berupa zat organik atau anorganik bersifat dapat terurai atau tidak dapat terurai yang dianggap sudah tidak berguna lagi dan dibuang kelingkungan, (Slamet, 2002:15).
Berdasarkan difinisi diatas, maka dapat dipahami sampah adalah :

a. Sampah yang dapat membusuk (garbage), menghendaki pengelolaan yang cepat. Gasgas yang dihasilkan dari pembusukan sampah berupa gas metan dan $\mathrm{H} 2 \mathrm{~S}$ yang bersifat racun bagi tubuh.

b. Sampah yang tidak dapat membusuk (refuse), terdiri dari sampah plastik, logam, gelas karet dan lain-lain.

c. Sampah berupa debu/abu sisa hasil pembakaran bahan bakar atau sampah.

d. Sampah yang berbahaya terhadap kesehatan, yakni sampah B3 adalah sampah karena sifatnya, jumlahnya, konsentrasinya atau karena sifat kimia, fisika dan mikrobiologinya dapat meningkatkan mortalitas dan mobilitas secara bermakna atau menyebabkan penyakit reversible atau berpotensi irreversible atau sakit berat yang pulih.

e. menimbulkan bahaya sekarang maupun yang akan datang terhadap kesehatan atau lingkungan apabila tidak diolah dengan baik.

Pada bab ini akan diuraikan hal-hal yang berkaitan dengan persampahan yang dikutip dari beberapa literatur. Beberapa hal yang akan dikutip adalah, pengertian tentang sampah, jenis-jenis sampah, sistem pengelolaan sampah meliputi aspek teknis operasional, kelembagaan dan manajemen, hukum dan peraturan, aspek pembiayaan dan aspek peran serta masyarakat. Selain itu yang perlu dikemukakan dalam bab ini adalah sumber timbulan sampah, dampak negatif sampah dan permasalahan pengelolaan sampah.

\section{METODE}

Jenis penelitian ini yakni penelitian kualitatif. Unit analisis penelitian yakni implementasi kebijakan persampahan di Kota Makassar.

Subjek Penelitian ini adalah collaborative governance di Kota Makassar dan implementasinya dalam upaya untuk mewujudkan implementasi kebijakan persampahan. 


\section{HASIL DAN PEMBAHASAN}

\section{Gambaran Umum Kota Makassar}

Kota Makassar terbentuk sebagai suatu daerah otonom berdasarkan Undang-undang Republik Indonesia Tahun 1959 tentang Pembentukan Daerah-daerah Tingkat II di Sulawesi Selatan, sebagaimana yang tercantum dalam Lembaran Negara Republik Indonesia Tahun 1959 Nomor 74 dan Tambahan Lembaran Negara Republik Indonesia Nomor 1822. Kota Makassar menjadi ibukota Provinsi Sulawesi Selatan berdasarkan Undang-Undang Nomor 13 Tahun 1965 (Lembaran Negara Tahun 1965 Nomor 94), dan kemudian berdasarkan Undang-Undang Nomor 8 Tahun 1965 Daerah Tingkat II Kotapraja Makassar diubah menjadi Daerah Tingkat II Kotamadya Makassar. Tanggal 31 Agustus 1971 nama Kota Makassar berubah menjadi Ujung Pandang, hal tersebut diatur berdasarkan Peraturan Pemerintah Nomor 51 Tahun 1971. Saat itu Kota Makassar dimekarkan dari $21 \mathrm{Km}^{2}$ menjadi $115,87 \mathrm{Km}^{2}$, terdiri dari 11 wilayah kecamatan, 62 lingkungan dengan penduduk sekitar 700 ribu jiwa. Pemekaran ini mengadopsi sebagian dari wilayah Kabupaten Gowa, Kabupaten Maros dan Kabupaten Pangkajene Kupulauan.

\section{Implementasi kebijakan persampahan berbasis Collaborative Governance di Kota Makassar}

Implementasi adalah suatu rangkaian aktifitas dalam rangka menghantarkan kebijakan kepada masyarakat sehingga kebijakan tersebut dapat membawa hasil sebagaimana yang diharapkan (Afan Gaffar, 2009: 295). Rangkaian kegiatan tersebut di mulai dari tahap persiapan seperangkat peraturan lanjutan yang merupakan interpretasi dari kebijakan tersebut.

Menurut hemat peneliti implementasi kebijakan adalah proses pengejewantahan peraturan-peraturan yang dibuat oleh pemerintah, mulai dari pemerintah pusat hingga pemerintah kabupaten/kota, dalam kaitannya dengan penelitian ini maka implemetasi kebijakan yang dimaksud adalah kebijakan persampahan di Kota Makassar.
Berikut ini akan dijelaskan mengenai tiga variable yang mempengaruhi keberhasilan proses implementasi menurut Soren C. Winter yakni perilaku hubungan antar organisasi, perilaku implementor, dan perilaku kelompok sasaran.

\section{a. Perilaku hubungan antar organisasi}

Perilaku hubungan antar organisasi adalah Perilaku hubungan yang berdimensi pada komitmen yaitu perjanjian (keterikatan) untuk melakukan sesuatu dan koordinasi antar organisasi yaitu adanya pergerakan organisasi /stakeholder atau kesatuan tindakan stakeholder yang terlibat ke arah tujuan Bersama.

Salah satu faktor yang berpengaruh terhadap keberhasilan implemetasi kebijakan persampahan di Kota Makassar adalah perilaku antar organisasi yang dibuktikan dengan komitmen dan koordinasi antar Lembaga/organisasi yang terkait kebijakan persampahan yakni UPT Bank Sampah, Yayasan Peduli Negeri, BSU AUDI, BSU HOKI, dan BSU Sukses Abadi.

Berikut ini akan dijelaskan mengenai komitmen dan koordinasi antar Lembaga/organisasi yang terkait kebijakan persampahan dalam hal ini adalah UPT Bank Sampah, Yayasan Peduli Negeri, BSU AUDI, BSU HOKI, dan BSU Sukses Abadi.

\section{1) Komitmen}

Komitmen Lembaga terkait sudah begitu jelas yakni mengelola persampahan di Kota Makassar. Cheema dan Rondinelli dalam Subarsono (2008) karakteristik dan kapabilitas agen pelaksana tergambar pada bagaimana komitmen petugas terhadap program. Komitmen para pelaku pengelolaan persampahan di Kota Makassar dapat terlihat melalui hasil wawancara yang dilakukan oleh peneliti berikut ini.

Berdasarkan hasil wawancara, peneliti menarik kesimpulan bahwa setiap pelaku kebijakan persampahan di Kota Makassar (UPT Bank Sampah, YPN dan BSU) sudah berkomitmen untuk berkolaborasi mengimplementasikan kebijakan persampahan di Kota Makassar. 
2) Koordinasi

Menurut penjelasan Van Meter dan Van Horn yang dikutip dalam Subarsono (2005) menjelaskan dalam berbagai kasus, implementasi sebuah program terkadang perlu didukung dan dikoordinasikan dengan instansi lain agar tercapai keberhasilan yang diinginkan. Sementara menurut Cheema dan Rondinelli yang dikutip dalam Subarsono (2008) mengatakan bahwa pembagian fungsi antar instansi yang pantas.

Koordinasi antara UPT Bank Sampah, Yayasan Peduli Negeri, BSU AUDI, BSU HOKI, dan BSU Sukses Abadi selama ini dilakukan secara berkala, setiap sekali dalam sepekan, dua kali sepekan, atau bahkan tiga kali dalam sepekan. Dalam pelaksanaan koordinasi tersebut hal yang paling urgen dilakukan yaitu untuk mengetahui sejauh mana implementasi pengelolaan persampahan di Kota Makassar. Walaupun koordinasi yang terbangun selama ini belum begitu maksimal, namun usaha untuk terus mengintensifkan koordinasi akan tetap diupayakan.

Berdasarkan hasil wawancara, peneliti menarik kesimpulan bahwa setiap pelaku kebijakan persampahan di Kota Makassar (UPT Bank Sampah, YPN dan BSU) sudah berkoordinasi dalam mengimplementasikan kebijakan persampahan di Kota Makassar.

b. Perilaku implementor aparat tingkat bawah

Perilaku implementor yaitu adanya kontrol politik yaitu kendali dalam pelaksanaan kebijakan yang dibuat dan dilakukan oleh pemerintah, kontrol organisasi yaitu sebagai proses mengendalikan, mengawasi dan mengevaluasi suatu kegiatan, dan etos kerja yaitu semangat kerja dan norma-norma profesional yang meliputi kemampuan yang tinggi dan berpegang teguh kepada nilai moral.

Salah satu factor yang mempengaruhi implementasi kebijakan persampahan di Kota Makassar adalah perilaku implemetor atau pengambil kebijakan level bawah yang di mana dimensinya adalah diskresi.

Berikut ini akan dijelaskan terkait dengan perilaku aparat tingkat bawah (implementor) kebijakan yakni Kontrol organisasi dan profesionalisme aparat.

1) Kontrol Organisasi
Kontrol organisasi berfungsi untuk melakukan pengawasan terhadap aktifitas yang dikerjakan oleh staf/karyawan, baik di dalam lingkungan kerja maupun di di lua lingkungan kerja sehingga staf bisa melakukan pekerjaan dengan baik sesuai tupoksinya. Dalam implementasi kebijakan ini, control organisasi tetap dilakukan oleh pimpinan kepada staf. Dalam setiap tugas yang dilakukan staf selalu melaporkan pekerjaannya kepada atasan, sehingga dengan demikian bisa disimpulkan bahwa control organisasi dalam implementasi kebijakan persampahan telah berjalan dengan baik.

Berdasarkan hasil wawancara di atas, peneliti menarik kesimpulan bahwa setiap pelaku kebijakan persampahan di Kota Makassar (UPT Bank Sampah, YPN dan BSU) telah melakukan control organisasi terhadap staf/aparatnya masing-masing.

\section{2) Profesionalisme Aparat}

Selain kontrol terhadap staf, perlu juga diperhatiakn terkait dengan etos kerja yaitu semangat kerja dan norma-norma profesionalisme staf/aparat yang meliputi kemampuan yang tinggi dan berpegang teguh kepada nilai moral.

Faktor sumber daya manusia akan menjadi urgen dalam proses implementasi kebijakan, karena jika SDM lemah maka sudah bisa dipastikan bahwa kebijakan tidak akan bisa diimplementasikan secara baik. Sumber daya manusia merupakan factor yang sangat urgen dalam implementasi kebijakan agar berjalan secara efektif. Menurut Edward III apabila implementor kekurangan sumber daya, maka proses implementasi tidak akan berjalan secara efektif.

Proses implementasi kebijakan akan mengalami hambatan karena factor profesionalisme aparat yang masih terbilang kurang, hasil temuan penelitian menggambarkan bahwa etos kerja staf/aparat sangat baik akan tetapi tidak dibaregi dengan profesionalisme.

Berdasarkan hasil wawancara di atas, peneliti menarik kesimpulan bahwa setiap pelaku kebijakan persampahan di Kota Makassar (UPT Bank Sampah, YPN dan BSU) telah memiliki SDM atau Staf yang sudah mumpuni dalam menjalankan tugasnya sebagai 
implementor kebijakan persampahan di Kota Makassar.

\section{c. Perilaku Kelompok Sasaran}

Perilaku kelompok sasaran yaitu perilaku kelompok sasaran meliputi respon positif atau negatif masyarakat dalam mendukung atau tidak mendukung suatu kebijakan yang disertai adanya umpan balik berupa tanggapan kelompok sasaran terhadap kebijakan yang dibuat.

Salah satu factor yang mempengaruhi keberhasilan implementasi kebijakan persampahan di Kota Makassar adalah perilaku kelompok sasaran yang dimensinya yaitu respon positif atau respon negative dari kelompok sasaran.

1) Dukungan Positif

Menurut pandangan Mazmanian dan Sabatier yang dikutip dalam Subarsono (2005) mengatakan bahwa dukungan public terhadap sebuah kebijakan sangat pentig, tanpa dukungan kelompok sasaran maka kebijakan tidak akan maksimal dijalankan.

Berdasarkan hasil wawancara di atas, peneliti menarik kesimpulan bahwa BSU yang juga sebagai kelompok sasaran memberikan respon yang positif atas kebijakan persampahan di Kota Makassar.

\section{2) Dukungan Negatif}

Tanggapan negatif dalam implementasi kebijakan seperti halnya dua sisi mata uang yang tidak bisa dipisahkan. Secara umum para pelaku kebijakan implementasi persampahan di Kota Makassar lebih khusus kepada para pemilik Bank Sampah Unit (BSU) adalah kelompok masyarakat yang memiliki inisiatif untuk mendirikan dan mengelola Bank Sampah sebagi upaya untuk mengurangi volume sampah di Kota Makassar.

Menurut pandangan Mazmanian dan Sabatier yang dikutip dalam Subarsono (2005) mengatakan bahwa keberhasilan implementasi dipengaruhi oleh variable lingkungan dimana kondisi social ekonomi masyarakat menjadi perhatian. Penegakan aturan acapkali terkendala kondisi social ekonomi masyarakat setempat yang mengatasnamakan hak ulayat, akibatnya respon negative akan muncul apabila aturan diterapkan pada kelompok sasaran. Hasil penelitian ini menunjukkan respon negative yang timbul adalah kurangnya kesadaran para pemilik Bank Sampah Unit pada proses penimbangan sampah.

\section{Collaborative Governance dalam implementasi kebijakan Persampahan di Kota Makassar}

Pada penelitian ini peneliti membagi ke dalam 4 tahapan collaborative governance dalam implementasi persampahan di Kota Makassar sebagaimana model collaborative governance Ansell And Gash yakni sebagai berikut:

\section{a. Kondisi Awal}

Berdasarkan hasil wawancara dapat disimpulkan bahwa kondisi awal kolaborasi implememntasi persampahan berjalan dengan baik yang dibuktikan dengan komitmen masing-masing pihak implementor.

b. Desain Institusional

Berdasarkan hasil wawancara dapat ditarik kesimpulan bahwa sejak awal desain institusional untuk kebijakan persampahan ini sudah diatur dan didesain oleh kekuatan institusional.

\section{c. Kepemimpinan fasilitatif}

Berdasarkan hasil wawancara dapat ditarik kesimpulan bahwa kepemimpinan fasilitattif sudah berjalan dalam program implementasi kebijakan persampahan di Kota Makassar.

\section{d. Proses Kolaboratif}

Berdasarkan hasil wawancara di atas maka dapat disimpulkan bahwa segala proses kolaborasi implementasi persamapahan di Kota Makassar sudah berjalan dengan baik

\section{Faktor-faktor determinan dalam Implementasi kebijakan persampahan berbasis Collaborative Governance Kota Makassar}

Berikut ini adalah Faktor determinan dalam implememntasi kebijakan persampahan 
bebrbasis Collaborative Governance Kota Makassar :

\section{Faktor Pendukung}

Faktor-faktor pendukung dalam implemetasi kebijakan persampahan berbasis collaborative governance adalah sebagai berikut:

\section{a. Komunikasi}

Dalam proses komunikasi kebijakan terdapat tiga hal penting yang dibahas, yakni transmisi, konsistensi, dan kejelasan (clarity). Faktor pertama yang mendukung implementasi kebijakan adalah transmisi. Seorang pejabat yang mengimlementasikan keputusan harus menyadari bahwa suatu keputusan telah dibuat dan suatu perintah untuk pelaksanaanya telah dikeluarkan. Faktor kedua yang mendukung implementasi kebijakan adalah kejelasan, yaitu bahwa petunjuk-petunjuk pelaksanaan kebijakan tidak hanya harus diterima oleh para pelaksana kebijakan, tetapi komunikasi tersebut harus jelas. Sedangan Faktor ketiga yang mendukung implementasi kebijakan adalah konsistensi, yaitu jika implementasi kebijakan ingin berlangsung efektif, maka perintahperintah pelaksanaan harus konsisten dan jelas.

b. Dukungan Sumber Daya

Pelaksanaan suatu kebijakan publik akan sangat sulit apabila pada pengimlementasiannya tidak cukup dukungan untuk pelaksanaan kebijakan tersebut. Komponen sumberdaya ini terdiri dari jumlah staf, keahlian dari para pelakasana kebijakan, informasi yang jelas dan relevan agar cukup untuk mengimplementasikan kebijakan dan pemenuhan sumber-sumber terkait pelaksanaan kebijakan, adanya kewenangan yang menjamin bahwa program dapat diarahkan sebagaiman yang diharapkan, serta adanya fasilitas-fasilitas pendukung yang dapat dipakai untuk melakukan kegiatan program seperti dana dan sarana prasarana.

\section{KESIMPULAN}

Berdasarkan hasil dari wawancara dan pembahasan sebelumnya, maka peneliti dapat menyimpulkan hal-hal berikut ini : 1) Implementasi kebijakan persampahan berbasis collaborative governance di Kota Makassar sudah terlaksana. 2) Perilaku organisasi dan antar organisasi telah mengimplemtasikan kebijakan persampahan berbasis collaborative governance di Kota Makassar. Setiap pelaku kebijakan persampahan di Kota Makassar (UPT Bank Sampah, YPN dan BSU) sudah memiliki komitmen untuk berkolaborasi mengimplementasikan kebijakan persampahan di Kota makassar. Hal tersebut dapat dilihat dari pernyataan masing-masing pihak dan dibuktikan dengan adanya koordinasi antar Lembaga. 3) Setiap pelaku kebijakan persampahan di Kota Makassar (UPT Bank Sampah, YPN dan BSU) telah mengimplemetasikan secara diskresi kebijakan persampahan tersebut. 4) Perilaku kelompok sasaran diimplemetasikan sesuai respon positif dari setiap Bank Sampah Unit (BSU) yang juga sebagai kelompok sasaran. Hal tersebut dapat dilihat dari adanya respon yang positif atas kebijakan persampahan di Kota Makassar. 5) Faktor pendukung dalam proses penerapan prinsip-prinsip good governance adalah faktor komunikasi dan factor dukungan sumberdaya.

\section{DAFTAR PUSTAKA}

Adi Sasmita, Sakti adji. 2011. Jaringan transportasi (teori dan analisis) Yogyakarta: Graha Ilmu.

Amri, Nurmaida. 2016. Sistem penerapan pengelolaan persampahan kota Makassar. Universitas Hasanuddin: jurnal.

Basriyanto. 2007. Memanen smapah. Yogyakarta: Kanisius

Cleveland, Harlan. 1972. The Future Executive: A Guide for Tomorrow's Managers. New York: Harper \& Row.

Gaffar, Afan. 2009. Politik Indonesia : Transisi menuju demokrasi. Yogyakarta : Cetakan V, Pustaka Pelajar

Hardijanto. 2008. Pengembangan modal intelektual (peran strategik fungsi managemen sumber daya manusia). Makalah pada kongres dan seminar ilmiah nasional IPI ke VII Bandung.

Kartini. 2009. Faktor-faktor yang mempengaruhi keputusan masyarakat menabung sampah serta dampak keberadaan bank sampah gemah ripah (kasus masyarakat dusun badegan, 
Yogyakarta).Skripsi.Fakultas Ekonomi dan managemen.Ipb.

Marzuki, P. F dan Lumeno, S.S.Persepsi risiko terhadap penyediaan dan pengelolaan

Mulyadi. Deddy.2015. Perilaku oragnisasi dan kepemimpinan pelayanan. Bandung : Alfabeta.

Slamet 2002. Ekologi lingkungan hidup dan pembangunan, Jakarta: Djembatan.

Sudarmo. (2011). Isu-Isu Administrasi Publik. Solo: Smart Media

Thompson, Ann Marie. 2006."Colaboration Process inside the balck box",Public Administration on Review.66 (S1).2032.

Zulkifli. 2010.Manajemen Sumber Daya Manusia

\section{Undang-Undang}

Undang-Undang Nomor 18 Tahun 2008 tentang Pengelolaan Sampah terdiri atas pengurangan sampah dan penanganan sampah.

Undang-Undang Republik Indonesia Nomor 18 Tahun 2008 Tentang Perlindungan dan Pengelolaan Sampah yang berbunyi: Masyarakat dapat berperan dalam pengelolaan sampah yang diselenggarakan oleh pemerintah dan/atau pemerintah daerah

\section{Jurnal}

Ansell, C. \& Gash, A. (2007). Collaborative governance in theory and practice.Journal of Public Administration Research and Theory, 18, 543-571

Ashalakshmi, K.S. Arunachalam, P. (2010). Solid waste management: a case study of Arppukara Grama Panchayatof Kottayam District, Kerala (India). Journal of Global Economy, 6(1), 34-63

Bachtiar, H., Hanafi, I. \& Rozikin, M. (2013). Pengembangan bank sampah sebagai bentuk partisipasi masyarakat dalam pengelolaan sampah (studi pada koperasi bank sampah malang). Jurnal Administrasi Publik, 3(1), 128-133

Slamet Rosyadi 2013 Permodelan Sampah Pemukiman Berbasis Manajemen Kolaborasi Universitas Jenderal Soedirman

Emerson, Kirk dan Tina Nabatchi. 2015. Collaborative Governance Regime.
Washington: Georgetown University. Hal 5-6

Cleveland, Harlan. 1972. The Future Executive: A Guide for Tomorrow's Managers. New York: Harper \& Row. Hal 13

Rhodes, R.A.W. 1996.The New Governance: Governing Without Government. Journal Political Studies Volume 44 No 4. 